Jurnal Penelitian Bahasa dan Sastra Indonesia V1.i1 (89-99)

\title{
STRATEGI PENGGUNAAN KOSAKATA DAN TATA BAHASA DALAM BERITA HARIAN UMUM INDEPENDEN SINGGALANG
}

\author{
Dina Ramadhanti \\ Program Studi Pendidikan Bahasa dan Sastra Indonesia \\ STKIP PGRI Sumatera Barat \\ Email: dina_ramadhanti89@yahoo.com \\ Submitted :10-05-2016, Reviewed:15-10-2016, Accepted:31-10-2016 \\ http://dx.doi.org/10.22202/jg.2015.v1i1.1160
}

\begin{abstract}
This article aims to describe the strategy of the use of vocabulary and grammer in general daily news $i$ Singgalang newspaper. The method used is descriptive method to descripe the use of vocabulary and grammer in writing news writer. The discusiion carried out in accordance with the opinion expressed by Roger Flower, etal. Vocabulary and grammer in general daily news in singgalang newspaper tend to marginalize the victim because writers to write descriptions of the perpetrator, while the victim semed to be ignored. Vocabulary used tend vocabulary and grammer marginalizations tend syntax used passive or passivation and nominalition resulting in the removal of the perpetrator in the news. Victims tend to be the main core of the problem
\end{abstract}

Keyword: vocabulary, grammer, news

\begin{abstract}
ABSTRAK
Artikel ini bertujuan untuk menggambarkan strategi penggunaan kosa kata dan tata bahasa secara umum berita harian i Singgalang koran. Metode yang digunakan adalah metode deskriptif untuk mendeskripsikan penggunaan kosa kata dan tata bahasa dalam menulis penulis berita. discusiion yang dilakukan sesuai dengan pendapat yang dikemukakan oleh Roger Flower, dkk. Kosa kata dan tata bahasa secara umum berita harian di koran Singgalang cenderung meminggirkan korban karena penulis untuk menulis deskripsi pelaku, sementara korban semed untuk diabaikan. Kosakata yang digunakan cenderung kosakata dan marginalizations tata cenderung sintaks yang digunakan pasif atau pasif dan nominalition mengakibatkan penghapusan pelaku dalam berita. Korban cenderung menjadi inti utama dari masalah
\end{abstract}

Keyword: kosakata, tata bahasa, berita 


\section{PENDAHULUAN}

Wacana merupakan satuan bahasa tertinggi dalam tataran linguistik. Wacana dapat berupa lisan dan tulisan. Wacana juga berupa bentuk pengungkapan pikiran dan gagasan penulis tentang suatu fenomena yang berkembang di masyarakat. Analisis wacana merupakan suatu kajian yang meneliti atau menganalisis bahasa yang digunakan secara alamiah baik dalam bentuk lisan maupun tulisan. Wacana khususnya wacana tulis perlu dianalisis atau dikaji secara kritis oleh pemakai bahasa karena wacana digunakan untuk meyajikan segala informasi yang berguna bagi pembaca. Pembaca dapat mengetahui isu atau fenomena yang sedang terjadi di berbagai tempat dengan adanya wacana. Dalam upaya untuk menyampaikan informasi wacana semakin berkembang, bahkan digunakan sebagai sarana pertarungan antarkelompok untuk menyampaikan aspirasinya. Selain itu, kata wacana bahkan dijadikan jargon untuk menyatakan suatu informasi yang belum jelas kebenarannya. Tentu hal ini perlu menjadi perhatian karena wacana sesungguhnya adalah alat komunikasi yang digunakan untuk menyampaikan aspirasi. Sebagai sarana untuk menyalurkan aspirasi penulis khususnya dalam menyampaikan informasi, wacana juga mengandung berbagai ideologi dan paham tertentu. Ideologi dan kekuasaan dalam kajian wacana menjadi bahasan penting karena seorang analis dapat menentukan cara penyajian suatu teks dalam suatu media. Secara mendalam juga dapat dikaji pihak mana yang berkuasa dan pihak mana yang termarjinalkan.

Wacana memiliki pengaruh yang luar biasa bagi pembaca dalam mengungkap fenomena yang terjadi. Bagi sebagian orang wacana yang ada dalam surat kabar kadangkala hanya sebagai bacaan pengisi waktu luang. Padahal jika kita analisis secara kritis kita dapat menemukan ideologi seorang penulis dalam tulisan yang dibuatnya. Kadangkala untuk memperjuangkan ideologi yang dianutnya, maka secara langsung atau tidak langsung penulis juga memarjinalkan ideologi yang lain. Oleh karena itu, pembaca yang kritis dapat memahami wacana dari sudut pandang yang berbeda dengan menerapkan analisis wacana kritis dalam mengkaji fenomena yang terjadi.

Salah satu cara yang digunakan penulis untuk mengedepankan suatu ideologi adalah dengan mendayagunakan kosakata tertentu dan tata bahasa dalam menuliskan suatu berita atau wacana. Melalui kosakata yang digunakan maka penulis dapat menyajikan wacana sesuai dengan ideologi yang dianut. Penulis juga dengan bebas mengedepankan ideologi dengan atau tanpa memarjinalkan ideologi lain melalui kosakata dan tata bahasa yang digunakan. 
Pendayagunaan kosakata dan tata bahasa tertentu dapat mempengaruhi pemaknaan wacana dalam sebuah berita. Jika ditelaah lebih jauh, kosakata bisa menaikkan bahkan bisa menjatuhkan suatu ideologi. Dalam pengedepanan ideologi ini penulis cenderung berhati-hati dalam menggunakan kosakata. Kosakata atau bahasa yang digunakan menggambarkan cara pandang terhadap suatu realitas. Selain itu, memungkinkan seseorang mengontrol dan mengatur pengalaman pada realitas sosial.

Penulis memiliki cara atau strategi tertentu dalam menggunakan kosakata dan tata bahasa. Cara yang dilakukan berbeda-beda antara kelompok yang satu dengan yang lain. Hal ini dilatarbelakangi oleh pengalaman budaya, sosial, dan politik yang berbeda. Bahkan Fowler, dkk (dalam Eriyanto, 2000:134) menganalisis pengalaman dan politik yang berbeda dapat dilihat dari bahasa yang dipakai yang menggambarkan pertarungan sosial terjadi. Arti penting dari klasifikasi ini dapat dilihat dari sebuah peristiwa yang sama dapat dibahasakan dengan bahasa yang berbeda. Misalnya perkosaan dapat dibahasakan dengan memerkosa, meniduri, menggagahi, memerawani, dan sebagainya.

Menurut Roger Fowler dkk (dalam Eriyanto, 2000:135--149) kosakata yang digunakan dalam wacana media dapat berupa kosakata: membuat klasifikasi, kosakata: membatasi pandangan, kosakata: pertarungan wacana, dan kosakata: pemarjinalan. Kosakata membuat klasifikasi maksudnya menyederhanakan atau abstraks dari realita, suatu realita yang dikategorisasi dengan cara tertentu pada akhirnya dapat dibedakan dengan yang lain. Misalnya suatu realitas dipandang sebagai masalah dalam negeri, di pihak lain bisa saja realitas itu dipandang sebagai masalah internasional.

Kosakata membatasi pandangan maksudnya kosakata yang digunakan dapat membatasi pemikiran kita dalam memandang dan memaknai suatu realitas. Kosakata yang digunakan cenderung meminta kita untuk memahami suatu realitas dengan cara tertentu bukan yang lain. Misalnya kasus pertikaian antara kaum Muslimin dan kaum Nasrani. Dengan kosakata yang digunakan kadangkala secara tidak langsung meminta kita untuk memahami peristiwa itu sebagai kasus pertikaian semata bukan kasus pembataian kaum Muslimin oleh kaum Nasrani.

Kosakata pertarungan wacana maksudnya mengklaim pendapat sendirilah yang benar bukan pendapat orang lain. Mereka mempunyai klaim kebenaran, dasar pembenar, dan penjelas mengenai suatu masalah. Bukan hanya memiliki perbedaan versi, tetapi juga berusaha agar versinya yang benar dan paling menentukan dalam mempengaruhi opini publik. Misalnya kasus baku hantam TNI dengan GAM di Aceh yang 
menyebabkan rakyat meninggal karena tewas ditembak, versi TNI mengatakan mereka melepaskan senjata karena terpaksa karena adanya kontak senjata antara TNI dan GAM sedangkan versi GAM, TNI terus melakukan penembakan terhadap rakyat secara membabi buta. Dalam hal ini dapat dilihat terjadi pertarungan antara TNI dan GAM dalam memandang peristiwa penembakan rakyat di Aceh.

Kosakata pemarjinalan maksudnya kata yang digunakan bukan sebagai sesuatu yang netral tetapi membawa implikasi ideologis tertentu. Dengan kata lain pemarjinalan berupa upaya untuk membentuk pendapat umum, meneguhkan, dan membenarkan pihak sendiri dan mengucilkan pihak lain. Jika terjadi suatu kasus kriminal dengan kosakata yang digunakan dapat ditentukan aktor mana yang dibenarkan dan aktor mana yang dimarjinalkan/dikucilkan. Misalnya seorang gadis seksi diperkosa oleh pemuda karena mabuk. Di dalam kalimat tersebut terdapat pemarjinalan terhadap aktor perempuan. Seorang gadis diperkosa karena berpenampilan seksi sedangkan pemuda melakukan pemerkosaan karena mabuk. Jika pemuda itu tidak mabuk, maka ia tidak akan melakukan pemerkosaan. Dalam hal ini sangat jelas terjadi pemarjinalan terhadap aktor perempuan. Hal ini sesuai dengan pendapat Badara (2012:95) yang menyatakan bahwa sesungguhnya pemarjinalan merupakan penggambaran tidak semestinya aktor perempuan di dalam wacana berita surat kabar.

Tata bahasa yang dimaksud berhubungan dengan penggunaan kalimat aktif dan pasif dalam menulis berita. Dengan menggunakan kalimat pasif, maka secara tidak langsung terjadi penghilangan pelaku dalam kasus yang diberitakan. Penggunaan tata bahasa dalam menulis berita juga menjadi perhatian penulis. Tata bahasa yang digunakan juga mencerminkan ideologi penulis berita. Tata bahssa juga berhubungan dengan adanya pasivasi dan nominalisasi kalimat, sehingga terjadi penghilangan pelaku.

Salah satu berita dalam surat kabar yang dapat diidentifikasi strategi penggunaan kosakata dan tata bahasanya adalah dalam berita pembunuhan dalam Harian Umum Independen Singgalang. Berita-berita pembunuhan tersebut akan dianalisis berdasarkan kosakata dan tata bahasa untuk melihat apakah terjadi pemarjinalan terhadap aktor atau penghilangan pelaku dengan pasivasi atau nominalisi karena pihak penulis ingin mengedepankan ideologi. Oleh karena itu, artikel ini bertujuan untuk menjelaskan strategi penggunaan kosakata dan tata bahasa dalam berita Harian Umum Independen Singgalang. Dengan mengkaji kosakata yang digunakan dapat diketahui aktor mana yang dibenarkan dan aktor mana yang dimarjinalkan dan dengan tata bahasa 
yang digunakan akan terlihat apakah penulis berusaha menghilangkan pelaku atau tidak. Analisis ini didasarkan pada teori analisis wacana kritis yang dikemukakan oleh Roger Fowler, dkk.

\section{Metode}

Pembahasan yang dilakukan bersifat menjelaskan fenomena yang ditemukan pada objek yang dibahas. Oleh karena itu, dalam artikel ini digunakan jenis penelitian kualitatif dengan metode deskriptif. Moleong (2002:7) menyatakan bahwa penelitian kualitatif adalah metode penelitian yang lebih mementingkan proses daripada hasil. Metode deskriptif maksudnya data yang dikumpulkan tidak diolah dengan kata-kata tetapi lebih mengutamakan kedalaman penghayatan terhadap masalah yang dibahas. Data yang dikumpulkan menggunakan analisis isi (content analysis) dengan tujuan untuk menganalisis isi wacana atau opini tersebut secara mendalam.

Objek yang akan dikaji adalah wacana berita pembunuhan dalam Harian Umum Independen Singgalang yang dikumpulkan selama tujuh hari Edisi Mei 2013. Berita yang dimaksud yaitu "Dibacok Anak, Ibu Merangkak Minta Tolong", "Terdakwa Pembunuhan dikejar Keluarga Korban", "M.Yusuf Tebas Dada Saudaranya dengan Sabit", "Tidak Terima dibilang PSK: Istri Muda Tikam Istri Tua", "Terdakwa Pembunuhan Kabur dari Rumah Sakit Jiwa", "Tiga Hari Kabur dari RSJ Sa'anin
Lando ditangkap di Lubuk Alung", dan "Diduga Dendam Pengendara ditusuk". Teknik pengumpulan data adalah dengan teknik dokumentasi. Langkah-langkah yang dilakukan dalam menganalisis data berikut ini. (1) Membaca wacana dalam Harian Umum Independen Singgalang secara keseluruhan. (2) Menemukan kosakata mana yang dominan dan tata bahasa yang digunakan dalam wacana berita. (3) Membahas kosakata dan tata bahasa yang digunakan dengan mengaitkan dengan pengalaman atau fenomena yang terjadi, kemudian disimpulkan. Berdasarkan langkah analisis data yang dilakukan maka artikel ini bertujuan untuk menjelaskan strategi penggunaan kosakata dan tata bahasa dalam Harian Umum Independen Singgalang.

\section{PEMBAHASAN}

Wacana berita di surat kabar mengandung ideologi tertentu yang berpengaruh pada berita yang dimuat. Ideologi disembunyikan dalam kosakata dan tata bahasa yang digunakan. Kosakata yang dimaksud ini berupa kosakata membuat klasifikasi, kosakata membatasi pandangan, kosakata pertarungan wacana, dan kosakata marjinalisasi. Tata bahasa yang dimaksud berupa pasivasi dan nominalisasi sehingga dalam berita terjadi penghilangan aktor pelaku. 
Dalam wacana berita pembunuhan yang dikumpulkan selama tujuh hari dalam Harian Umum Independen Singgalang Edisi Mei 2013 akan dibahas strategi penggunaan kosakata dan tata kalimat dalam penyajian berita. Dalam hal ini akan terlihat keberpihakan media kepada pelaku atau korban dan akan terlihat pihak mana yang dibenarkan dan mana yang dimarjinalkan.

\section{Analisis Wacana Berita I "Dibacok Anak Ibu Merangkak Minta Tolong"}

Wacana berita I menceritakan

tentang kasus pembunuhan yang dilakukan oleh seorang anak yang diduga mengalami gangguan jiwa dengan tega membunuh Ibu kandungnya sendiri. Pada judul digunakan kata dibacok ini membuktikan bahwa anak dengan tega membunuh ibunya secara sadis. Kata bacok berarti penusukan secara berulang-ulang. Pada lead adanya kata habisi. Ini membuktikan dari kosakata yang digunakan terdapat marjinalisasi terhadap korban yaitu ibu yang tanpa dapat melawan dibunuh secara sadis oleh anaknya sendiri.

Tata bahasa yang digunakan dalam wacana berita ini terlihat dengan adanya pasivasi dalam artian banyaknya penggunaan kalimat pasif. Misalnya dibacok anak, ibu merangkak minta tolong. Dalam kalimat tersebut adanya pasivasi seolah-olah perilaku pelaku hal yang biasa. Selain itu dalam berita disajikan pembelaan diri korban. korban diduga mengalami gangguan jiwa. Kata diduga, dalam hal ini berarti pelaku secara tidak sengaja membunuh ibunya. Jika ia tidak mengalami gangguan jiwa maka pelaku tidak akan membunuh.

Secara umum berita ini memperlihatkan keberpihakan media kepada pelaku. Sedangkan korban tidak terlalu diberitakan. Bagaimana kondisi korban saat pasca pembunuhan. Berita yang disajikan lebih banyak menceritakan pelaku yang mengalami gangguan jiwa, keseharian pelaku, dan pembelaan-pembelaan pelaku melakukan pembunuhan. Selain itu, pelaku dinyatakan mengalami gangguan jiwa. Dalam hal ini kasus pembunuhan dianggap hal biasa tidak terlalu berpengaruh. Media dalam hal ini lebih cenderung menceritakan pelaku bukan korban.

\section{Analisis Wacana Berita II "Terdakwa Pembunuhan dikejar Keluarga Korban"}

Wacana berita II ini menceritakan tentang kasus pembunuhan yang dilakukan suami (pelaku) terhadap istrinya (korban). Kosakata yang digunakan dalam wacana berita ini juga cenderung marjinalisasi terhadap korban ditandai dengan adanya kata dibacok, ditinggalkan memperlihatkan pelaku menganiaya korban hingga tewas tak 
bernyawa. Selain itu, dalam berita juga digunakan nominalisasi yaitu pembunuhan, pembacokan. Kata-kata tersebut seolah-olah menyamarkan pelaku pembunuhan sadis.

Tata bahasa yang digunakan cenderung menggunakan kalimat pasif yaitu pasivasi dan nominalisasi. Berita yang disajikan lebih banyak menceritakan tentang kejadian sebelum pembunuhan terjadi. Berita yang disajikan tidak terlihat keberpihakan media karena berita diceritakan secara beruntun dari pihak saksi. Selain itu juga tidak terlihat pembelaan diri dari pelaku.

Secara umum dapat dikatakan bahwa meskipun berita disajikan lebih banyak berasal dari saksi mata, namun sedikit banyaknya media juga menganggap kasus pembunuhan hal yang biasa karena tidak dibahas lebih banyak mengenai alasan terjadi pembunuhan hanya kondisi korban yang berlumuran darah setelah pembunuhan berlangsung.

\section{Analisis Wacana Berita III "M. Yusuf Tebas Dada Saudaranya dengan Sabit"}

Wacana berita III ini menceritakan tentang kasus pembunuhan yang dilakukan seorang adik kepada kakaknya. Kasus pembunuhan yang diceritakan dalam berita ini juga lebih cenderung berpihak kepada pelaku ini terlihat dari kosakata dan tata bahasa yang digunakan. Dari judul terlihat bahwa pelaku tega membunuh saudaranya dengan sabit. Pada judul tidak terlihat keberpihakan media. Setelah dibaca secara keseluruhan kosakata dan tata kalimat yang digunakan mengandung keberpihakan media kepada pelaku.

Pada berita disajikan bahwa pembunuhan dilakukan pelaku tidak terduga dan tidak ada niat untuk membunuh tetapi karena pelaku panik dan sering dilecehkan korban. Kata-kata pembunuhan pada kalimat ratusan warga menyaksikan rekonstruksi pembunuhan. Kata pembunuhan disana terlihat pelaku disamarkan. Pembunuhan terjadi tanpa diduga oleh pelaku. Dalam berita juga disajikan pembelaan-pembelaan korban yang menyatakan bahwa pelaku tidak bermaksud membunuh. Selain itu dalam berita yang disajikan terjadi marjinalisasi terhadap korban bahwa korban dibunuh karena korban selalu melecehkan pelaku.

\section{Analisis Wacana Berita IV"Tidak Terima dibilang PSK, Istri Muda Tikam Istri Tua"}

Wacana berita IV menceritakan
tentang kasus pembunuhan yang
dilakukan oleh istri muda pada istri tua
karena istri tua mengatakan istri muda
sebagai PSK. Kasus pembunuhan yang
diceritakan dalam wacana berita ini juga
lebih banyak memarjinalkan korban.
Selain itu berita disajikan lebih banyak
dari pihak pelaku bukan korban. Korban


dijadikan penyebab terjadinya penikaman terhadap dirinya. Korban yang menyerang ke kediaman pelaku. Pelaku tidak terima dikatakan sebagai PSK. Oleh karena itu, pelaku memecahkan botol dan pelaku mengatakan tiba-tiba korban mengeluarkan darah. Pelaku bersikeras bukan dia yang melakukan penikaman itu.

Berita yang disajikan meskipun menggunakan kalimat aktif tetapi tetap saja memarjinalkan korban. Misalnya sebelum kejadian, korban mendatangi pelaku, korban meneriaki pelaku dengan sebutan pekerja seks komersial, korban melempar rumah kos dan rumah kos dilempari dengan batu. Dalam kalimat-kalimat di atas terlihat bahwa terjadi pemarjinalan terhadap korban. Korban dianggap telah menjadi penyebab pembunuhan. Dalam hal ini jelas yang salah adalah korban, karena jika korban tidak melakukan penyerangan terhadap pelaku maka penikaman tidak akan terjadi.

banyak Berita yang disajikan lebih pembelaan-pembelaan pelaku. Berita yang disajikan seolah-olah terlihat keberpihakan media kepada pelaku. Korban yang teraniaya dan diduakan oleh suaminya tidak menjadi perhatian media. Perhatian media hanya pada pelaku sedangkan kondisi korban tidak menjadi perhatian. Pelaku akan diadili setelah adanya konfirmasi korban baik-baik saja.

\section{Analisis Wacana Berita V "Terdakwa Pembunuhan Kabur dari Rumah Sakit Jiwa"}

Wacana berita $\mathrm{V}$ menceritakan terdakwa pembunuhan yang dirawat di rumah sakit jiwa melarikan diri. Dalam hal ini terlihat bahwa kasus pembunuhan terjadi karena pelaku mengalami gangguan jiwa. Pada lead digunakan kata pembunuhan memperlihatkan bahwa pelaku disamarkan dan kasus pembunuhan merupakan hal yang biasa. Secara tidak langsung terdapat pemarjinalan terahadap korban. Pelaku direhabilitasi karena saat persidangan pelaku memberikan keterangan berbelit-belit. Setelah dinyatakan sembuh, ternyata pelaku berhasil melarikan diri.

Secara umum berita yang disajikan memperlihatkan kondisi pelaku ketika persidangan yang memberikan keterangan berbelit-belit. Oleh karena itu, pelaku dinyatakan mengalami gangguan jiwa dan direhabilitasi di rumah sakit jiwa. Setelah dinyatakan sembuh, pelaku berhasil melarikan diri dari kawalan polisi. Kondisi korban yang dibunuh pelaku tidak terlalu dijelaskan karena media lebih banyak menceritakan tentang kondisi pelaku pasca terjadi pembunuhan. 


\section{Analisis Wacana berita VI "Tiga Hari Kabur dari RSJ Sa'anin, Lando Ditangkap di Lubuk Alung"}

\begin{abstract}
Wacana berita VI menceritakan tentang pelaku pembunuhan yang melarikan diri dari Rumah Sakit Jiwa Sa'anin Padang. Pelaku ditangkap karena masih harus menyelesaikan kasus pembunuhan yang dilakukannya pada besannya sendiri. Berita yang disajikan merupakan lanjutan dari berita $\mathrm{V}$ di atas yang menceritakan tentang kasus pembunuhan dengan tersangka Lando. Diduga kuat mengalami ganggguan jiwa Lando, direhab di RSJ Sa'anin namun begitu dinyatakan sembuh Lando melarikan diri dan berhasil ditangkap tiga hari berikutnya.

Tata bahasa yang digunakan juga banyak menggunakan kalimat pasif. Pelaku tidak terlibat langsung dalam pemberitaan. Berita disajikan sesuai keterangan yang diberikan oleh saksi dari pihak rumah sakit dan keluarga pelaku.
\end{abstract}

\section{Analisis Wacana VII "Diduga Dendam Pengendara ditusuk" Wacana VI menceritakan tentang kasus pembunuhan yang dilakukan oleh pelaku yang diduga dendam terhadap korban. Dari judul kata-kata diduga dendam pengendara ditusuk jelas memperlihatkan merjinalisasi terhadap korban sementara pelaku disamarkan. Kata yang digunakan}

secara tidak langsung menyatakan bahwa jika korban tidak melakukan sesuatu pada pelaku, maka pelaku tidak akan menaruh dendam, dan pelaku tidak akan menusuk korban. Dalam berita yang disajikan tidak diketahui dengan pasti pelaku pembunuhan. Akan tetapi dari berita yang disajikan terlihat bahwa korban dan pelaku saling mengenal. Dikarenakan dendam terhadap korban maka pelaku dengan sadis melakukan penusukan.

Tata bahasa yang digunakan banyak ditemukan nominalisasi yaitu penghilangan pelaku dengan menggunakan kata pembunuhan, penusukan. Dengan menggunakan kata-kata ini media cenderung memihak pada pelaku. Dari judul terlihat jika korban tidak memicu dendam, maka pelaku tidak akan membunuh korban. Pelaku jelas-jelas dibenarkan karena pelaku sebenarnya tidak ingin membunuh tetapi karena korban yang melakukan sesuatu pada pelaku, maka pelaku menjadi dendam dan terjadilah pembunuhan itu.

Tujuh berita yang telah dianalisis di atas, memperlihatkan bahasa kosakata dan tata bahasa yang digunakan dalam menulis berita sangat mempengaruhi pemaknaan berita oleh pembaca. Pembaca dapat mengetahui bahwa dengan menggunakan pasivasi/kalimat pasif dan nominalisasi dalam menulis berita, cenderung terlihat keberpihakan media terhadap pelaku. Pelaku melakukan pemnbunuhan 
terhadap korban karena korban yang memicu hal itu terjadi. Apabila korban tidak memicu peristiwa itu, maka pembunuhan yang dilakukan oleh pelaku tidak akan terjadi. Hal ini menggambarkan bahwa korban dimarjinalkan. Korban tidak diberikan kesempatan membela diri dan bahkan tidak terlalu menjadi bahasan utama dalam wacana.

\section{SIMPULAN}

Wacana berita pembunuhan di Harian Umum Independen Singgalang pada umumnya lebih memihak pada pelaku. Hal ini terlihat pada dari kosakata yang digunakan dan tata bahasa dalam kalimat-kalimat berita yang disajikan. Berita yang disajikan lebih mengarah pada kondisi pelaku dan pembelaan-pembelaan diri pelaku, sedangkan korban dimarjinalkan karena seolah-olah korban sebagai pemicu pembunuhan. Sementara kondisi korban akibat pembunuhan tidak dijelaskan. Padahal derita yang dirasakan korban tidak sebanding dengan yang dialami pelaku. Pelaku diceritakan melakukan pembunuhan selain dipicu oleh korban, pelaku juga mengalami gangguan jiwa. Padahal sebenarnya yang menjadi inti berita adalah kasus pembunuhan yang dialami korban bukan derita yang dialami pelaku. Dalam hal ini terlihat bahwa pembunuhan merupakan hal yang biasa terjadi dalam masyarakat. Dengan kata lain, media tidak memandang penyajian berita dari banyak sisi tetapi dari satu sisi. Berita yang disajikan kadangkala hanya berupa pembelaan-pembelaan diri dari pelaku. Selain itu, juga berupa keterangan-keterangan dari saksi yang kadangkala saksi pun berpihak pada pelaku. Ini jelas memperlihatkan bahwa dalam wacana media korban sering dimarjinalkan.

Agar tidak terjadi marjinalisasi pada pihak korban, maka penulis berita perlu memiliki sifat netral dalam menyajikan berita. Karena dengan netralnya penulis berita, maka tidak akan terjadi kesenjangan antara pelaku dan korban. Perbuatan keji yang dilakukan pelaku haruslah menjadi perhatian dengan tidak mengesampingkan perbuatan pelaku terhadap korban. Korban pun harus menjadi perhatian utama karena korban mengalami penganiayaan dari pelaku. Terlepas dari siapa yang salah sebagai penyebab pembunuhan, tetap pembunuhan dianggap sebagai perbuatan yang sangat tercela dan perlu dihindari. Oleh karena itu, meskipun media ingin memegang teguh ideologinya dalam menulis berita, media tidak boleh mengenyampingkan nilai-nilai kemanusiaan dalam menyajikan berita.

\section{DAFTAR PUSTAKA}
Badara, Aris. 2012. Analisis Wacana:
Teori, Metode, dan Penerapannya pada Wacana 
ISSN: $2442-8485$

JURNAL GRAMATIKA

E-ISSN: 2460-6319

Jurnal Penelitian Bahasa dan Sastra Indonesia V1.i1 (89-99)

Media. Jakarta: Kencana Prenata Media Grup.

Eriyanto. 2001. Analisis Wacana:

Pengantar Analisis Teks Media.

Yogyakarta: LKIS.
Harian Umum Independen Singgalang Edisi Mei 2013

Moleong, Lexy J. 2002. Metodologi Penelitian Kualitatif. Bandung: Rosda Karya. 